\title{
Pembelajaran Keterampilan Membuat Ikan Bakar Bagi Anak
}

\section{Hambatan Pendengaran}

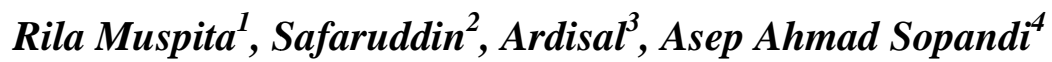 \\ ${ }^{1234}$ Universitas Negeri Padang, Indonesia \\ rilamuspita@fip.unp.ac.id
}

\section{INFORMASI ARTIKEL}

Terkirim 04 Oktober 2018

Revisi 18 Oktober 2018

Diterima 08 Novem ber 2018

\section{Kata kunci:}

Pembelajaran, Keterampilan, Ikan

Bakar, Anak Hambatan Pendengaran

\begin{abstract}
ABSTRAK
Penelitian ini didasari dari kurangnya ketersedian lapangan pekerjaan bagi anak dengan hambatan pendengaran. Sementara pemerintah yang tertuang undang-undang sudah berupaya penuh untuk memfasilitasi dalam pengembangan penyandang disabilitas pada umumnya dan anak dengan hambatan pendengaran khususnya. Selain itu kurikulum juga sudah mendukung untuk terlaksananya pembelajaran yang berbasis soft skill dalam bentuk keterampilan vokasional sehingga pengkajian mengenai model untuk pembelajaran dirasa perlu terus dilakukan. Penelitian ini dilakukan untuk menemukan model pembelajaran keterampilan membuat ikan bakar yang dilakukan di sekolah sehingga nanti akan menemukan acuan untuk mengembangkan model pembelajaran sesuai kebutuhan anak. Mengingat bahwasanya model merupakan seluruh rangkaian penyajian materi ajar yang meliputi segala aspek sebelum sedang dan sesudah pembelajaran. Sehingga target pembelajaran dapat terlaksana dan tertata dengan jelas. Penelitian ini berangkat dari paradigma post-positivistik dengan pendekatan kualitatif. Pendekatan dan metode ini dipilih dengan mempertimbangkan bahwa pendekatan dan metode ini lebih membuka peluang untuk mendapatkan informasi yang mendalam tentang proses dan dapat mengembangkan sebuah model pembelajaran.
\end{abstract}

\section{Pendahuluan}

Peserta didik adalah seseorang yang memiliki potensi dasar yang perlu dikembangkan melalui pendidikan baik secara fisik maupun psikis baik pendidikan itu dilakukan di lingkungan keluarga, sekolah, maupun di lingkungan masyarakat di mana anak tersebut berada. Komponen peserta didik sangatlah beragam, termasuk di dalamnya penyandang disabilitas. Penyandang disabilitas adalah seseorang yang mengalami keterbatasan fisik, intelektual, mental, dan/atau sensorik dalam jangka waktu yang lama. Anak penyandang disabilitas juga mengalami keterlambatan dalam proses pertumbuhan atau perkembangandibandingkan dengan anak-anak lain seusianya. Sehingga mereka memerlukan pelayanan pendidikan khusus.

Salah satu dari penyandang disabilitas yang memungkinkan untuk membuka usaha secara professional dibidang vokasional terkhusus tata boga adalah anak dengan hambatan pendengaran. anak dengan hambatan pendengaran merupakan bagian dari penyandang disabilitas yang mengalami hambatan dalam pendengaran yang bersifat abstrak. Namun mereka masih mampu melakukan kegiatan yang bersifat kongkrit. Didalam proses belajar mengajar, anak dengan hambatan pendengaran pada umumnya memerlukan waktu yang relatif lama dibandingkan dengan anak pada umumnya. Hal ini disebabkan hambatan yang dimilikinya. Dimana hambatan utama dari anak dengan hambatan pendengaran adalah kurang lancarnya dalam berkomunikasi dengan orang lain. Namun bukan berarti mereka sama sekali tidak bias meningkatkan kemampuannya sesuai dengan tingkat teman sebayanya.

Permasalahan yang sangat menonjol dari anak dengan hambatan pendengaran ini adalah kesulitan dalam mencari lapangan pekerjaan yang sesuai dengan kebutuhan anak. Sering kali setelah tamat dari sekolah luar biasa anak hanya berada di rumah dan ataupun bekerja hanya mampu bertahan beberapa bulan saja karena sulitnya untuk menyesuaikan diri di tempat kerja. Akibatnya anak kembali lagi ke sekolah dan atau menganggur di rumah.

Pemberian pendidikan keterampilan menjadi solusi untuk pengembangan karier anak dengan hambatan pendengaran. Pendidikan keterampilan yang secara khusus menjadi muatan kurikulum dalam bentuk pelajaran adalah keterampilan vokasional. Berdasarkan kurikulum tersebut pendidikan keterampilan vokasional diberikan kepada semua peserta didik. Proporsi muatan isi kurikulum satuan pendidikan terkhusus SMALB terdiri atas $40 \%$ $50 \%$ aspek akademik dan 50\%- $60 \%$ aspek keterampilan. Keterampilan vokasional yang diajarkan di sekolah terdiri atas keterampilan tata boga, tata busana, tata rias, dan perbengkelan. Hal ini sebagaimana tertuang dalam UU no. 8 tahun 2016 pasal 56 yang berbunyi bahwa pemerintah dan pemerintah daerah wajib memberikan jaminan, perlindungan, dan pendampingan kepada penyandang disabilitas untuk berwirausaha dan mendirikan badan usaha sesuai dengan ketentuan peraturan perundang-undangan. Sehingga membuktikan bahwa pemerintah juga harus mempersiapkan penyandang disabilitas dalam dunia usaha.

Pada sekolah luar biasa khususnya SMALB, kurikulum vokasional yang digunakan saat ini salah satunya adalah keterampilan tata boga. Kurikulum tersebut memiliki pembelajaran tentang membuat hidangan lauk pauk. Berdasarkan survei yang dilakukan oleh peneliti dibeberapa rumah makan ternama khusus ikan bakar di Kota Padang yang paling diminati oleh warga Kota Padang adalah ikan nila bakar. Dari data yang diperoleh oleh peneliti sekitar lima ratus ekor ikan nila bakar dapat terjual dalam sehari. Ini hanya pada rumah makan dan pondok ikan bakar ternama di Kota Padang. Selain itu juga didukung dengan mudahnya mendapatkan ikan nila di kota Padang. Berdasarkan survei yang dilakukan oleh peneliti tersebut, hal ini sangat berpeluang bagi anak dengan hambatan pendengaran untuk dapat membuka usaha terkait dengan banyaknya minat warga Kota Padang terhadap ikan nila bakar.

Sehubung dengan paparan tersebut untuk menciptakan suatu pembelajaran yang terarah dan terpandu perlu adanya kajian untuk mendapatkan sebuah model keterampilan dalam membuat ikan bakar yang nantinya dapat meningkatkan produktivitas dan mengoptimalkan kemampuan anak dengan 
hambatan pendengaran. Diharapkan anak dengan hambatan pendengaran produktivitasnya dapat meningkat dan mampu mandiri untuk membuka sebuah usaha sehingga memiliki jiwa yang kompetitif dan dapat berkontribusi bagi pembangunan bangsa. Selain dengan hal tersebut bahwa jika produktivitas anak muncul maka akan teriring dengan tumbuhnya kemampuan berinovasi. Maka dari itu penting kiranya melakukan kajian-kajian mengenai pembelajaran keterampilan hingga nantinya mendapatkan model pembelajaran yang sesuai dengan kebutuhan anak.

\section{Metode}

Penelitian ini dilakukan di kota Padang yaitu pada sekolah luar biasa YPAC Sumatera Barat. Lokasi ini dipilih karena peneliti melihat masih adanya anak dengan hambatan pendengaran tamatan sekolah ini yang menanggur. Selain itu sekolah ini memiliki anak hambatan pendengaran yang sedang duduk di bangku SMALB. Melihat permasalahan yang ada maka peneliti akan megembangkan model pembelajaran keterampilan vokasional membuat ikan bakar dalam upaya meningkatkan produktivitas anak dengan hambatan pendengaran menggunakan pendekatan kualitatif. Penelitian kualitatif adalah penelitian yang berlandaskan pada filsafat postpositivisme, digunakan untuk meneliti pada kondisi obyek yang alamiah, dimana peneliti adalah sebagai instrumen kunci, teknik pengumpulan data dilakukan secara triangulasi (gabungan), analisis data bersifat kualitatif dan hasil penelitian kualitatif lebih menekankan makna daripada generalisasi (Sugiyono, 2013, hlm 8).

Karakteristik dari penelitian ini adalah : (1) lingkungan alamiah, dimana data lapangan dikumpulkan di lokasi dimana partisipan mengalami isu atau masalah yang akan diteliti, (2) peneliti sebagai instrumen kunci, dimana peneliti mengumpulkan data sendiri melalui dokumentasi, observasi pelaku dan wawancara dengan para partisipan, (3) beragam sumber data dan (4) bersifat penafsiran. (Sugiyono, 2013, hlm 261-262).

\section{Hasil Penelitian dan Pembahasan}

Adapun bentuk rencana pelaksanaan pembelajaran membuat ikan bakar pada mata pelajaran keterampilan tata boga pada kelas X di SLB YPAC guru menyatakan bahwa saat pembelajaran menggunakan model pembelajaran lansung. Diketahui bahwa model pembelajaran lansung Menurut Trianto (2014: 93) adalah salah satu pendekatan mengajar yang dirancang khusus untuk menunjang proses belajar siswa yang berkaitan dengan pengetahuan deklaratif dan pengetahuan prosedural yang terstruktur dengan baik yang dapat diajarkan dengan pola kegiatan yang bertahap, selangkah demi selangkah. Pembelajaran langsung dapat berbentuk ceramah, demonstrasi, pelatihan atau praktek, dan kerja kelompok.

Model pengajaran langsung ini membutuhkan prosedur yang terstruktur dalam pembelajaran. Prosedur yang terstruktur tersebut dapat tertuang dalam rancangan program pembelajaran. Sehingga ketika guru menggunakan model pengajaran langsung, guru harus menyiapkan rancangan program pembelajaran terlebih dahulu. Sementara pada prakteknya guru tidak menggunakan rancangan program pembelajaran. Guru hanya menyatakan bahwa model yang digunakan menggunakan model pengajaran langsung.

Model pengajaran langsung memiliki beberapa keterbatasan yang di paparkan oleh Ahmad sudrajatdimana model pengajaran langsung berstandar pada kemampuan siswa untuk mengasimilasikan informasi dari kegiatan mendengar, mengamati dan mencatat. Model pengajaran langsung sulit untuk mengatasi perbedaan dalam hal kemampuan, pengetahuan awal, tingkat pembelajaran, pemahaman, gaya belajar atau ketertarikan siswa. Materi yang disampaikan pada model pengajaran langsung bersifat kompleks, rinci, atau abstrak. Model pengajaran langsung sangat tergantung pada gaya komunikasi guru dan banyak melibatkan komunikasi satu arah. Selain itu model pengajaran langsung memiliki sedikit kesempatan untuk mengembangkan keterampilan sosial, interpersonal siswa, kemampuan menyelesaikan masalah, kemandirian dan kaingintahuan siswa.

Sementara itu adapun prinsip dalam pembelajaran bagi anak dengan hambatan pendengaran menurut Delphie (2006:104), berikut ini merupakan prinsip-prinsip pembelajaran tunarungu yaitu keterarahan wajah (face to face), Keterarah suaraan bagi yang masih memiliki sisa pendengaran, tanggap terhadap apa yang ingin dikatakan, berbicara dengan lafal yang jelas, penempatan tempat duduk yang tepat, penggunaan media pembelajaran, meminimalisasi metode ceramah.

Sehingga dapat dilihat antara penggunaan model pengajaran langsung dengan prinsip pembelajaran bagi anak hambatan pendengaran saling berseberangan. Sementra itu pada kurikulum 2013 jelas tuntutan pembelajaran tersebut meliputi 3 ranah sesuai dengan teori Taksonomi Bloom yaitu afektif, kognitif dan psikomotor. Akan tetapi hal demikian masih tidak cukup bagi pembelajaran anak dengan hambatan pendengaran. Seperti yang peneliti paparkan pada latar belakang permasalahan bahwasanya masih ada anak hambatan pendengaran setelah tamat sekolah yang menganggur. Tidak bias dipungkiri bahwa ini dapat diasumsikan merupakan hasil dari output sebuah pembelajaran. Pembelajaran yang dimaksud tersebut lebih kepada pembelajaran keterampilan. Pada analisis dilapangan proses pembelajaran masih berpatokan pada satu sumber yakni guru. Seharusnya pembelajaran bagi anak hambatan pendengaran harus memunculkan nilai produktivitas agar anak dapat berinovatif terutama pada pembelajaran keterampilan. Berdasarkan analisis di atas, peneliti mencoba merancang sebuah konsep model pembelajaran keterampilan membuat ikan bakar dalam upaya meningkatkan produktivitas anak dengan hambatan pendengaran.

\section{Kesimpulan}

Pada temuan mengenai pembelajaran keterampilan bagi anak dengan hambatan pendengaran tentang guru menggunakan model pengajaran langsung dinyatakan kurang tepat digunakan bagi anak dengan hambatan pendengaran. Dikarenakan model pengajaran langsung dengan prinsip pembelajaran bagi anak hambatan pendengaran saling berseberangan. Sementra itu pada kurikulum 2013 jelas tuntutan pembelajaran tersebut meliputi 3 ranah sesuai dengan teori Taksonomi Bloom yaitu afektif, kognitif dan psikomotor. Akan tetapi hal demikian masih tidak cukup bagi pembelajaran anak dengan hambatan pendengaran. Seperti yang peneliti paparkan pada latarbelakang permasalahan bahwasanya masih ada anak hambatan pendengaran setelah tamat sekolah yang menganggur. Tidak bias dipungkiri bahwa ini dapat diasumsikan merupakan hasil dari output sebuah pembelajaran. Selain itu anak hambatan pendengaran membutuhkan pembelajaran yang produktif dan inovatif untuk meningkatkan kecakapan hidupnya nanti. Sehingga membutuhkan pengembangan model dari hasil penelitian yang telah dilakukan.

\section{Daftar Rujukan}

Aji Permana, Septian. (2017). Strategi Pembelajaran IPS Kontenporer. Yogyakarta: Media Akademi

Daryanto, dkk. (2017). Pembelajaran Abad 21. Yogyakarta: Penerbit Gava Media

Eko Agustinova, Danu. (2015). Memahami Metode Penelitian Kualitaif. Yogyakarta: Calpulis

Iswari, Mega. (2008). Kecakapan Hidup Bagi Anak Berkebutuhan Khusus. Padang: UNP Press

Rusma. (2017). Belajar dan Pembelajaran Berorientasi Standar Proses Pendidikan. Jakarta: KENCANA

Rivai \& Murni. (2012). Education Management. Jakarta: PT. Raja Grafindo Persada

Soemardji. (1991). Pendidikan Keterampilan. Jakarta: Depdikbud Dikti

Sugiyono. (2013). Metode Penelitian Pendidikan. Bandung: Alfabeta

Sumekar, Ganda. (2009). AnakBerkebutuhanKhusus. Padang: UNP Press

Tisnawati, ernie, dkk. (2005). Pengantar Manajemen. Jakarta: KENCANA

Tjiptono, Fandi, dkk. (2012). Pemasaran Strategik. Yogyakarta: CV. Andi Offset

Tri Priyanti, Endah, dkk. (2017). Pembelajarn Reflektif : Model Pembelajaran Reflektif yang Responsif Teknologi. Tanggerang: Tira Smart

Trianto. (2014). Mendesain Model Pembelajaran Inovatif, Progresif dan Kontekstual. Jakarta: Prenadamedia Group 
Open Acces Jurnal: http://jpkk.ppj.unp.ac.id 